\title{
Mechanical Properties of Uni-Directional Long Bamboo Fiber/Bamboo Powder Composite Materials
}

\author{
Shinji Ochi \\ Mechanical Engineering, National Institute of Technology, Niihama College, Ehime, Japan \\ Email: $\underline{\text { s ochi@mec.niihama-nct.ac.jp }}$
}

Received 25 September 2014; revised 22 October 2014; accepted 14 November 2014

Copyright (C) 2014 by author and Scientific Research Publishing Inc.

This work is licensed under the Creative Commons Attribution International License (CC BY). http://creativecommons.org/licenses/by/4.0/

(c) (i) Open Access

\section{Abstract}

This paper describes the mechanical properties of the composite materials produced using long bamboo fiber and bamboo powder. Bamboo fiber and powder can be hot press-molded much like plastic materials, and the use of these materials in place of plastic products would reduce the environmental impact of extensive plastic use. In this study, the tensile and flexural properties of molded uni-directional long fiber reinforced composites made from bamboo fiber bundles and Bamboo powder were examined. The results showed that the tensile and flexural strength of bamboo fiber/powder composites were increased with increasing fiber content. On the other side, both strengths of composite were decreased with increasing molding temperature after $180^{\circ} \mathrm{C}$. The highest tensile and flexural strengths of the bamboo fiber reinforced bamboo powder composites specimens which were tested were recorded at 169.9 MPa and 221.1 MPa, respectively.

\section{Keywords}

Bamboo Fiber, Bamboo Powder, Composite Materials, Tensile Strength, Flexural Strength

\section{Introduction}

Plastic materials have accepted the important role in growth of modern society and they are massively used in broad fields; electronic products such as a copy machine and a printer, stationery goods such as automatic pencil and a clear file, a housing and interior of a vehicle such as a car and ship and much more. However, the great majority of plastic products are disposed into landfills after usage. In addition, global warming by increase of carbon dioxide poses a problem. Needless to say, this process is the easiest way and has high environmental loads. For these reasons, it is important to develop the charge of an alternate material of a plastics made of pe- 
troleum.

In order to reduce the environmental loads derived from the disposing of used plastic products, much more attention has been placed on the biodegradable plastic [1] [2]. This plastic can be perfectly resolved into water and carbon dioxide by the action of the microbes, as it is disposed in underground, and moreover there is no emission of the toxic gas in combusting. Recently, the biodegradable plastics have been applied to the commercial products such as the clear file ballpoint pens, garbage bags, tee of golf, fishing lines, wrapping paper and much more. Besides, recent studies have investigated the development of biodegradable composite materials using natural fibers such as flax [3], palm [3], pineapple [4], jute [5], kenaf [6], ramie [7] and hemp [8] as the reinforcement for biodegradable plastics. These studies have examined molding conditions, mechanical properties.

In the meantime, the bamboo was once one of the biomass resources grown in Japan. The bamboo has the characteristic feature that growth speed is quick, as compared with wood and it is used as part of daily life such as bamboo shoots for food and stalks for building materials. However, bamboo forests have fallen into ruin because of the import of inexpensive bamboo shoots and the appearance of plastic products. The present study investigated whether bamboo can be effectively used to replace plastic materials. The press-molded products were fabricated from bamboo powder, and the tensile strength, flexural strength and hardness of the resultant products were examined [9] [10].

The purpose of this research is to make the press-molded bamboo powder into still higher strength by using long bamboo fiber bundles. The uni-directional long bamboo fiber reinforced bamboo powder composites were fabricated from bamboo fiber bundle and bamboo powder, and the tensile and flexural properties of the resultant products were examined. These measured properties were subsequently compared to the mechanical properties of general plastic materials.

\section{Experimental Procedures}

\subsection{Materials}

In this research, bamboo powder and bamboo fiber bundle were used as matrix and reinforcement, respectively. Bamboo powder (Miki Takezaiten, Japan) of particle diameter of 50 - $150 \mu \mathrm{m}$ and bamboo fiber bundle (Ban, Japan) which have diameter of $100-300 \mu \mathrm{m}$ and length of $100 \mathrm{~mm}$ for flexural specimen and $200 \mathrm{~mm}$ for tensile specimen were used. Bamboo powder was prepared machining a bamboo trunk. Bamboo fiber bundle was taken out by steam explosion method. Steam explosion is the method when the water contains in bamboo is heated under high temperature and pressure, then bamboo is rapidly released to the atmosphere, so that the water evaporate into steam, result of parenchyma inside the bamboo shattered. Figure 1 and Figure 2 show photographs of bamboo powder and fibers used in this research, respectively.

\subsection{Molding Method of Bamboo Fiber/Bamboo Powder Composites}

The rate of bamboo fiber content is $0 \%, 50 \%$ and $100 \%$. Molding temperature is $160^{\circ} \mathrm{C}, 180^{\circ} \mathrm{C}$ and $200^{\circ} \mathrm{C}$. Table 1 was showed molding conditions in this research. The specimens were fabricated using a hot press machine and a metallic mold. Specifically, test specimens were made under varying conditions, the bamboo fiber and powder was added to the metallic mold and held at temperatures $160^{\circ} \mathrm{C}, 180^{\circ} \mathrm{C}$ and $200^{\circ} \mathrm{C}$ pressed at $65 \mathrm{MPa}$. The dimensions of bamboo fiber/bamboo powder copomosite specimens are $10 \mathrm{~mm} \times 200 \mathrm{~mm} \times 1 \mathrm{~mm}$ for tensile test specimen and $15 \mathrm{~mm} \times 100 \mathrm{~mm} \times 3 \mathrm{~mm}$ for flexural test specimen. Figure 2 and Figure 3 show shape
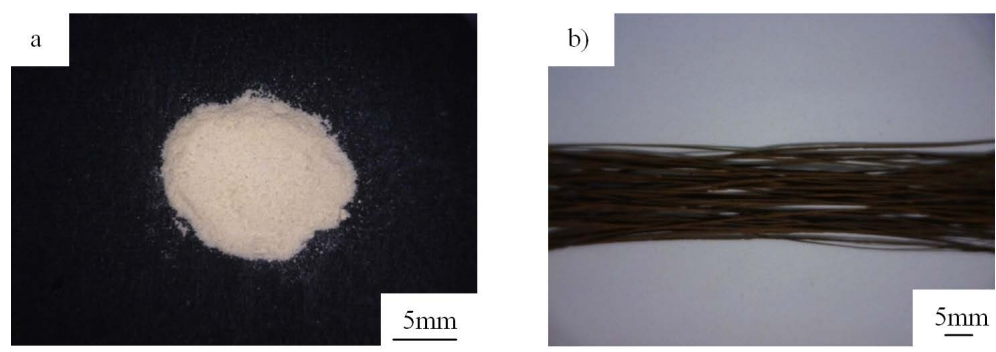

Figure 1. Photographs of Bamboo. (a) powder and (b) fiber. 

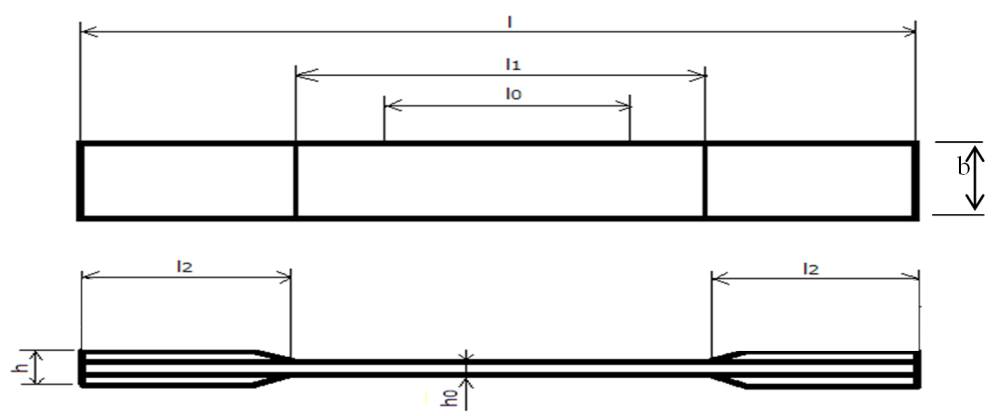

Figure 2. Shape and dimensions of tensile specimen $\left(\mathrm{l}=200 \mathrm{~mm}, \mathrm{l}_{0}=50\right.$ $\left.\mathrm{mm}, \mathrm{l}_{1}=70 \mathrm{~mm}, \mathrm{l}_{2}=65, \mathrm{~b}=10 \mathrm{~mm}, \mathrm{~h}_{0}=1 \mathrm{~mm}, \mathrm{~h}=3 \mathrm{~mm}\right)$.

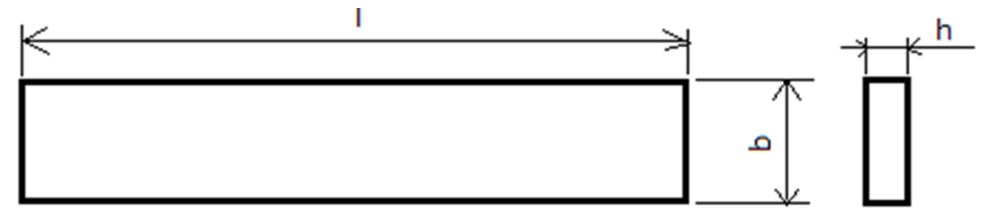

Figure 3. Shape and dimensions of flexural specimen $(\mathrm{l}=100 \mathrm{~mm}, \mathrm{~b}=15$ $\mathrm{mm}, \mathrm{h}=3 \mathrm{~mm})$.

Table 1. Molding conditions in this research.

\begin{tabular}{|c|c|c|}
\hline Molding temperature $\left({ }^{\circ} \mathrm{C}\right)$ & Bamboo powder (\%) & Bamboo powder (\%) \\
\hline \multirow{3}{*}{160} & 100 & 0 \\
\hline & 50 & 50 \\
\hline & 0 & 100 \\
\hline \multirow{3}{*}{180} & 100 & 0 \\
\hline & 50 & 50 \\
\hline & 0 & 100 \\
\hline \multirow{3}{*}{200} & 100 & 0 \\
\hline & 50 & 50 \\
\hline & 0 & 100 \\
\hline
\end{tabular}

and dimensions of tensile and flexural specimen, respectively.

\subsection{Method of Mechanical Testing}

Tensile tests and three-point flexural tests were conducted using a testing machine (SIMADZU Model AG-250 kNE), following JIS K7161 and JIS K7171, respectively. Tensile tests were performed at a strain rate of $1 \mathrm{~mm} / \mathrm{min}$ and a gauge length of $50 \mathrm{~mm}$. Flexural tests were performed at a crosshead speed of $1 \mathrm{~mm} / \mathrm{min}$ and a span length of $48 \mathrm{~mm}$. Five specimens were prepared and analyzed. A 95\% confidence interval was calculated by statistical analysis.

\section{Results and Discussions}

\subsection{Observation of Press Molded Products}

Photographs of the fabricated press molded products using bamboo powder (fiber content $0 \%$ ) are shown in Figure 4, with specimens molded at $160^{\circ} \mathrm{C}, 180^{\circ} \mathrm{C}$ and $200^{\circ} \mathrm{C}$ shown in Figures 4 (a)-(c), respectively. As seen 

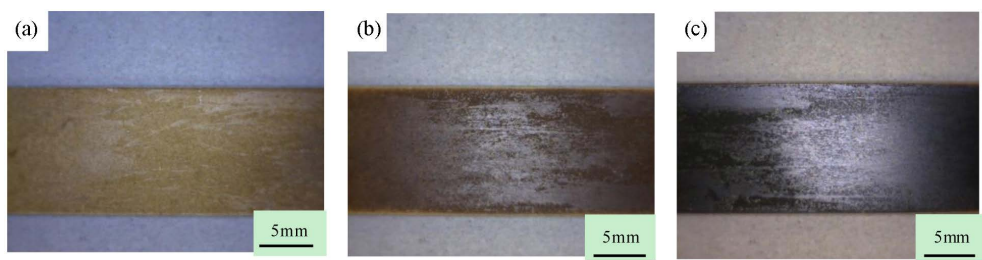

Figure 4. Photographs of surface of specimens (powder $100 \%$ ). a) $160^{\circ} \mathrm{C}$; b) $180^{\circ} \mathrm{C}$ and c) $200^{\circ} \mathrm{C}$.

in these figures, the color of the specimen molded at $160^{\circ} \mathrm{C}$ is pale yellow; however, the color darkened with rising molding temperature is the specimen exhibits a strong brown color at $200^{\circ} \mathrm{C}$. These results suggest that specimens browned on account of carbonization between $180^{\circ} \mathrm{C}$ and $200^{\circ} \mathrm{C}$.

Photographs of the fabricated press molded composites using bamboo fiber of $50 \%$ and powder of $50 \%$ are shown in Figure 5, with specimens molded at $160^{\circ} \mathrm{C}, 180^{\circ} \mathrm{C}$ and $200^{\circ} \mathrm{C}$ shown in Figures 5(a)-(c), respectively. As seen in these figures, the color powder and fibers of the specimen molded at $160^{\circ} \mathrm{C}$ is pale yellow and brown; however, the color of powder darkened with rising molding temperature is the specimen exhibits a strong brown color at $200^{\circ} \mathrm{C}$. These results suggest that specimens browned on account of carbonization between $180^{\circ} \mathrm{C}$ and $200^{\circ} \mathrm{C}$. As shown in these figures, at $160^{\circ} \mathrm{C}$, the fiber bundle and the parenchyma cell are clearly divided. On the other hand, it becomes increasingly difficult to distinguish the interface between the fiber bundle and the parenchyma cell with rising molding temperature. At $200^{\circ} \mathrm{C}$, all aspects become almost a uniform brown, making the interface between the fiber bundle and the parenchyma cell indistinguishable.

Photographs of the fabricated press molded products using bamboo fiber (fiber content 100\%) are shown in Figure 6, with specimens molded at $160^{\circ} \mathrm{C}, 180^{\circ} \mathrm{C}$ and $200^{\circ} \mathrm{C}$ shown in Figures 6(a)-(c), respectively. The color of the fiber only specimen at $160^{\circ} \mathrm{C}$ is already darkness. Color of bamboo fiber changed by steam explosion as shown in Figure 1(b)).

The relationship between the density of the composites and molding temperature is shown in Figure 7, and shows that the density of specimens the almost same value increased with rising molding temperature. The value indicated 1.39 to $1.42 \mathrm{~g} / \mathrm{cm}^{3}$.

\subsection{Flexural Strength of Composites}

Figure 8 shows the relationship between flexural strength and fiber content. From this figure, flexural strengths of each molding temperature increase linearly with increasing fiber content. Beside, the result of molding temperature at $200^{\circ} \mathrm{C}$ differs from other results. In the case of powder $100 \%$, adhesion will become strong increasing molding temperature indicates high value. However, strength of it selves of fiber decreased. Unidirectional bamboo fiber/bamboo powder composites fabricated with fiber content of $100 \%$ and molding temperature at $180^{\circ} \mathrm{C}$ have high flexural strength of $221.3 \mathrm{MPa}$.

Figure 9 shows the relationship between flexural strength and molding temperature. From this figure, in the case of composites of fiber content of $50 \%$ and $100 \%$, flexural strength is approximately equal to molding temperature at $160^{\circ} \mathrm{C}$ and $180^{\circ} \mathrm{C}$. However, strength decreased with increasing molding temperature in the case of $200^{\circ} \mathrm{C}$. The strength of the mold product decreased because strength of fiber in itself decreased as same as tensile strength. On the one hand, flexural strength fabricated using powder of $100 \%$ increase with rising molding temperature. It is considered that as a result of the increased powder bonding with rising molding temperature, the strength of the molded products increased.

Figures 10-12 show fracture behavior after flexural testing. Figure 10 shows specimen of all powder. The figure shows that the fracture of specimen is observable by all products.

Figure 11 and Figure 12 show specimen of fiber content of 50\% and 100\%, respectively. These figures show that the fracture of fibers is observable by all specimens. However, in the case of the specimen molded at $160^{\circ} \mathrm{C}$ (Figure 11(a)), adds to the fracture of fibers, delamination can be seen between the fiber bundle and the parenchyma cell, and bonding between the fiber bundle and the parenchyma cell is poor.

In the case of specimens molded at $180^{\circ} \mathrm{C}$ and $200^{\circ} \mathrm{C}$, they explained that this cause was due to internal voids and low shearing stress between fiber and powder. However, from Figure 9, flexural strength decreased with increasing molding temperature, the strength of the mold product decreased because strength of fiber in itself decreased [11]. 

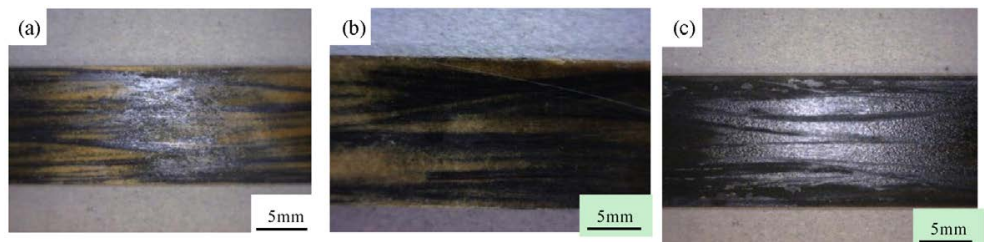

Figure 5. Photographs of surface of specimens (fiber $50 \%$ ). a) $160^{\circ} \mathrm{C}$; b) $180^{\circ} \mathrm{C}$ and c) $200^{\circ} \mathrm{C}$.
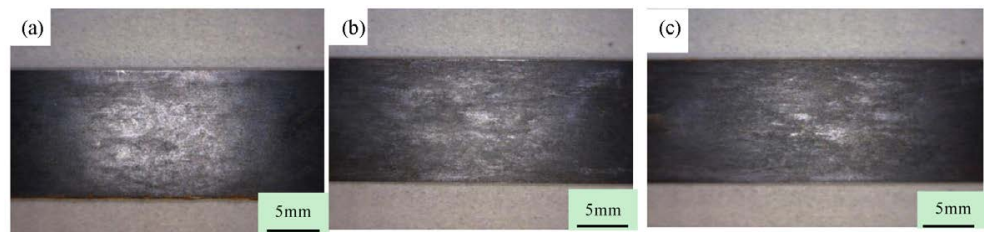

Figure 6. Photographs of surface of specimens (fiber $100 \%$ ). a) $160^{\circ} \mathrm{C}$; b) $180^{\circ} \mathrm{C}$ and c) $200^{\circ} \mathrm{C}$.

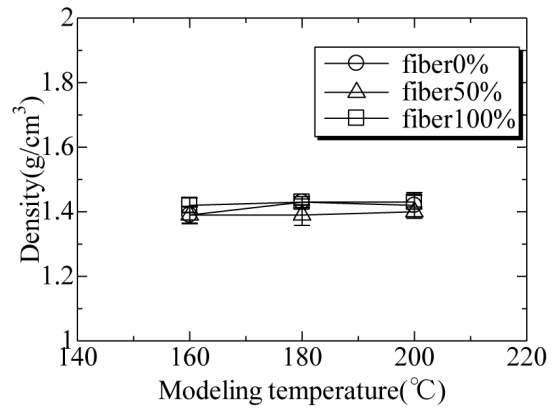

Figure 7. Relationship between density and molding temperature.

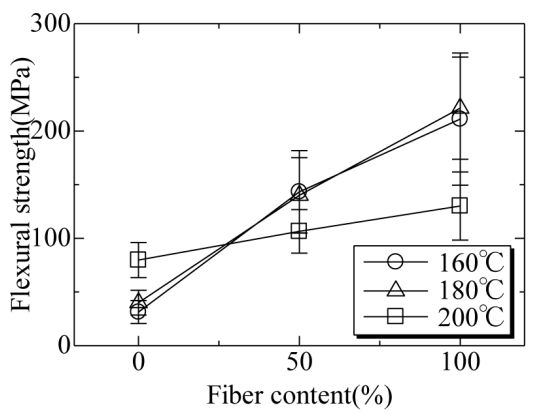

Figure 8. Relationship between flexural strength and fiber content.

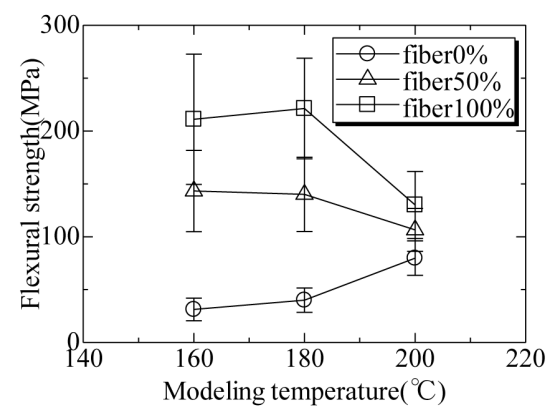

Figure 9. Relationship between flexural strength and molding temperature. 
Figure 13 shows the relationship between flexural modulus and fiber content. From this figure, flexural modulus increases linearly with increasing fiber content. Unidirectional bamboo fiber/bamboo powder composites fabricated with fiber content of $100 \%$ and molding temperature at $180^{\circ} \mathrm{C}$ have high flexural modulus of 32.9 GPa.

\subsection{Tensile Strength of Composites}

Figure 14 shows the relationship between tensile strength and fiber content. From this figure, tensile strengths increase with increasing fiber content. The tensile strengths were $169.9 \mathrm{MPa}$, in the samples with a fiber fraction of $100 \%$. Figure 15 shows the relationship between tensile strength and molding temperature. In the case of specimen of fiber content of $100 \%$, tensile strength decreased with increasing molding temperature. This was expected as it was known from an earlier study that the strength of natural fiber decreases at temperatures above $180^{\circ} \mathrm{C}$ [12]. Therefore, it is thought that the strength of the molded specimens created from fiber bundles decreased at $200^{\circ} \mathrm{C}$. On the other side, in the case of fiber content of $0 \%$ and $50 \%$, tensile strength increased with
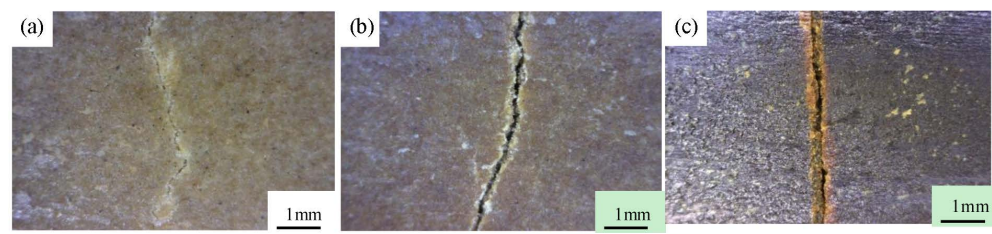

Figure 10. Fracture behavior after flexural test (powder 100\% molding temperature). a) $160^{\circ} \mathrm{C}$; b) $180^{\circ} \mathrm{C}$ and c) $200^{\circ} \mathrm{C}$ ).
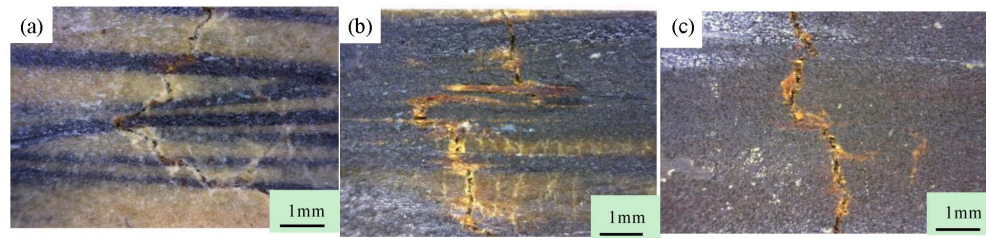

Figure 11. Fracture behavior after flexural test (fiber $50 \%$ molding temperature. a) $160^{\circ} \mathrm{C}$; b) $180^{\circ} \mathrm{C}$ and c) $200^{\circ} \mathrm{C}$ ).
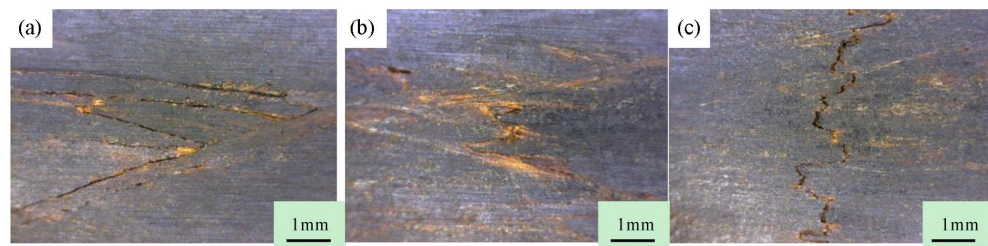

Figure 12. Fracture behavior after flexural test (fiber $100 \%$ molding temperature. a) $160^{\circ} \mathrm{C}$; b) $180^{\circ} \mathrm{C}$ and c) $200^{\circ} \mathrm{C}$ ).

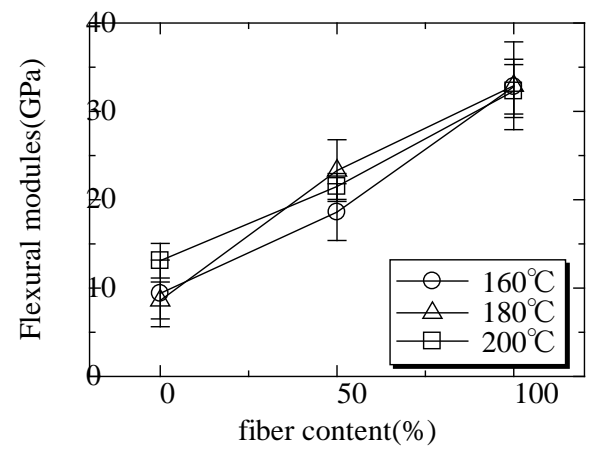

Figure 13. Relationship between flexural modus and fiber content. 
molding temperature. It is considered that it is because the adhesive strength of powder improved as this reason. Figures 16-18 show fracture behavior after tensile testing. The figure shows that the fracture of fibers is observable by all specimens. However, in the case of the specimen molded at $160^{\circ} \mathrm{C}$, adds to the fracture of fibers, the pull out of fibers be able to observe at the part. In the case of specimens molded at $180^{\circ} \mathrm{C}$ and $200^{\circ} \mathrm{C}$, the fiber bundle and the powder mixed homogeneously. However, from Figure 15, tensile strength decreased with increasing molding temperature, the strength of the mold product decreased because strength of fiber in itself decreased [11].

Figure 18 shows the relationship between tensile modulus and fiber content. From this figure, tensile modulus increases linearly with increasing fiber content. Unidirectional bamboo fiber/bamboo powder composites fabricated with fiber content of $100 \%$ and molding temperature at $160^{\circ} \mathrm{C}$ have high tensile modulus of $30.2 \mathrm{GPa}$.

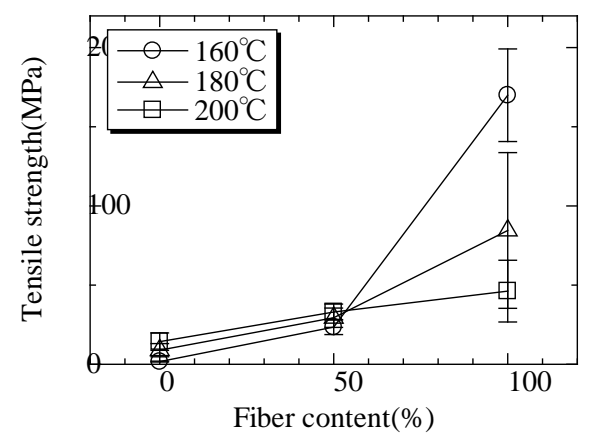

Figure 14. Relationship between tensile strength and fiber content.

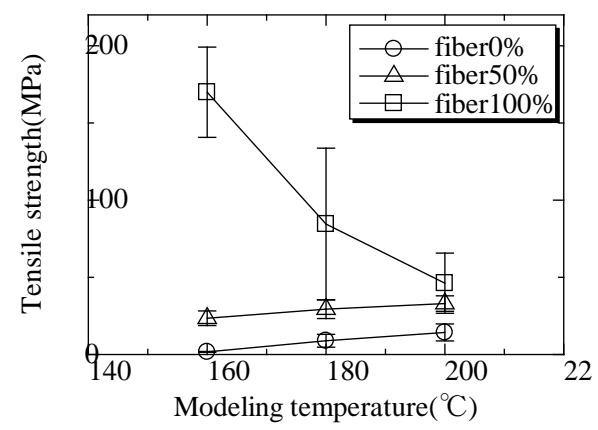

Figure 15. Relationship between tensile strength and fiber content.
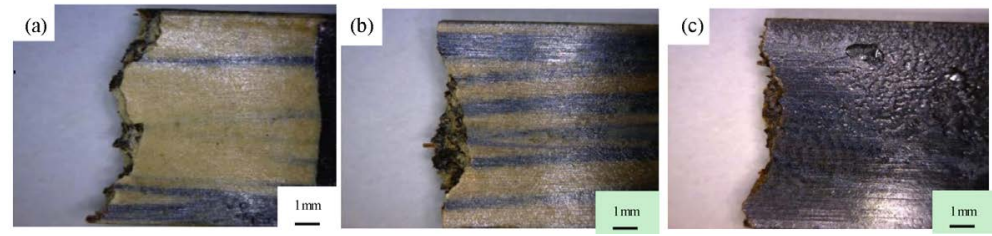

Figure 16. Fracture behavior after tensile test (fiber $50 \%$ molding temperature a) $160^{\circ} \mathrm{C}$; b) $180^{\circ} \mathrm{C}$ and c) $200^{\circ} \mathrm{C}$ ).
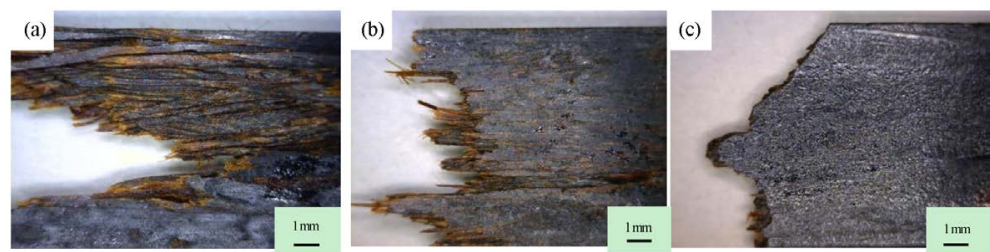

Figure 17. Fracture behavior after tensile test (fiber $100 \%$ molding temperature. a) $160^{\circ} \mathrm{C}$; b) $180^{\circ} \mathrm{C}$ and c) $200^{\circ} \mathrm{C}$ ). 


\subsection{Comparison with General Plastics}

Table 2 shows mechanical properties of general plastic materials. The density of bamboo composite indicated same as value of POM (polyacetal).

The tensile and flexural strength of common plastic materials, PE (polyehylene) is 8 - $23 \mathrm{MPa}$. Measurements of the press molded product of powder $100 \%$ indicated strengths nearly identical to that of polyethylene. Measurements of composite of $50 \%$ fibers indicated a tensile strength nearly identical to that of PP (polypropylene), and a flexural strength indicated same as strength of POM. The tensile and flexural strengths of the specimen of the fiber of $100 \%$ fabricated at $160^{\circ} \mathrm{C}$ exceeded the tensile and flexural strengths of POM. Based on these results, it is consider possible that bamboo fiber/powder composites could substitute effectively for conventional plastic products.

\section{Conclusion}

In this study, press-molded specimens consisting of uni-directional long bamboo fiber/bamboo powder compostoes was fabricated and examined for their density, tensile and flexural strengths. Obtained results are summarized as follows:

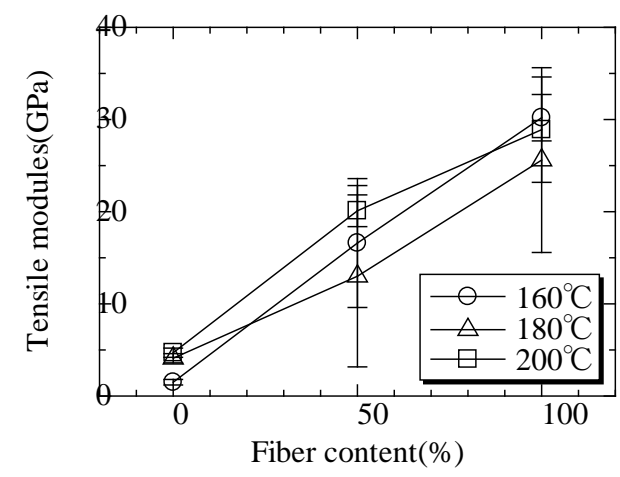

Figure 18. Relationship between tensile modules and fiber content.

Table 2. Mechanical properties of general plastic materials and bamboo fiber/bamboo powder composites [13].

\begin{tabular}{cccc}
\hline & Density & Tensile strength & Flexural strength \\
\cline { 2 - 4 } PE & $\left(\mathrm{g} / \mathrm{cm}^{3}\right)$ & $(\mathrm{MPa})$ & $(\mathrm{MPa})$ \\
$\mathrm{PP}$ & 0.94 & $8-23$ & $34-39$ \\
$\mathrm{PC}$ & 0.9 & $21-37$ & $42-56$ \\
$\mathrm{POM}$ & 1.2 & $56-67$ & $67-96$ \\
Powder $100 \% 160^{\circ} \mathrm{C}$ & 1.41 & $62-70$ & $100-110$ \\
Powder $100 \% 180^{\circ} \mathrm{C}$ & 1.4 & 1.7 & 31.3 \\
Powder $100 \% 200^{\circ} \mathrm{C}$ & 1.4 & 8.9 & 40.1 \\
$50 \%-50 \% 160^{\circ} \mathrm{C}$ & 1.4 & 14.3 & 79.8 \\
$50 \%-50 \% 180^{\circ} \mathrm{C}$ & 1.3 & 23.5 & 119.7 \\
$50 \%-50 \% 200^{\circ} \mathrm{C}$ & 1.3 & 29.4 & 140.1 \\
Fiber $100 \% 160^{\circ} \mathrm{C}$ & 1.3 & 33 & 106.5 \\
Fiber $100 \% 180^{\circ} \mathrm{C}$ & 1.3 & 169.9 & 211.1 \\
Fiber $100 \% 180^{\circ} \mathrm{C}$ & 1.4 & 84.5 & 221.3 \\
\hline
\end{tabular}


1. The density of the press-molded product indicated the almost same value increased with rising molding temperature. Density of composites indicated about $1.4 \mathrm{~g} / \mathrm{cm}^{3}$. This value is numerical value compared as polyacetal.

2. Tensile and flexural strengths increase linearly with increasing fiber content. In the case of fiber of $100 \%$ molded at $160^{\circ} \mathrm{C}$, the tensile and flexural strengths were $169.9 \mathrm{MPa}$ and $211.1 \mathrm{MPa}$, respectively.

3. The tensile and flexural strengths of specimens increased with rising fiber content. The strength of all powder specimens increased with rising molding temperature. Otherwise, the strength of $50 \%$ and $100 \%$ fiber decreased with rising molding temperature.

4. The tensile and flexural strengths exceeded the general-purpose engineering plastics such as polyacetal.

\section{References}

[1] Jia, W.W., Gong, R.H. and Hogg, P.J. (2014) Poly(Lactic Acid) Fibre Reinforced Biodegradable Composites. Composites Part B: Engineering, 62, 104-112. http://dx.doi.org/10.1016/j.compositesb.2014.02.024

[2] Ebnesajjad, S. (2012) Handbook of Biopolymers and Biodegradable Plastics. William Andrew, USA.

[3] Ibrahim, H., Farag, M., Megahed, H. and Mehanny, S. (2014) Characteristics of Starch-Based Biodegradable Composites Reinforced with Date Palm and Flax Fibers. Carbohydrate Polymers, 101, 11-19. http://dx.doi.org/10.1016/j.carbpol.2013.08.051

[4] Liu, W., Misra, M., Askeland, P., Drzal, L. and Mohanty, A.K. (2005) “Green” Composites from Soy Based Plastic and Pineapple Leaf Fiber: Fabrication and Properties Evaluation. Polymer, 46, 2710-2721.

[5] Plackett, D., Andersen, T.L., Pedersen, W.B. and Nielsen, L. (2003) Biodegradable Composites Based on Polylactide and Jute Fibres. Composites Science and Technology, 63, 1287-1296. http://dx.doi.org/10.1016/S0266-3538(03)00100-3

[6] Kwon, H.-J., Sunthornvarabhas, J., Park, J.-W., Lee, J.-H., Kim, H.-J., Piyachomkwan, K., Sriroth, K. and Cho, D. (2014) Tensile Properties of Kenaf Fiber and Corn Husk Flour Reinforced Poly(Lactic Acid) Hybrid Bio-Composites: Role of Aspect Ratio of Natural Fibers. Composites Part B: Engineering, 56, 232-237. http://dx.doi.org/10.1016/j.compositesb.2013.08.003

[7] Yu, T. and Li, Y. (2014) Influence of Poly(butylenes adipate-co-terephthalate) on the Properties of the Biodegradable Composites Based on Ramie/Poly(Lactic Acid). Composites Part A: Applied Science and Manufacturing, 58, 24-29. http://dx.doi.org/10.1016/j.compositesa.2013.11.013

[8] Song, Y.S., Lee, J.T., Ji, D.S., Kim, M.W., Lee, S.H. and Youn, J.R. (2012) Viscoelastic and Thermal Behavior of Woven Hemp Fiber Reinforced Poly(Lactic Acid) Composites. Composites Part B: Engineering, 43, 856-860.

[9] Ochi, S. (2011) Mechanical Properties of Press-Molded Products Using Bamboo Fiber of Different Shape. Journal of Materials Science and Engineering with Advanced Technology, 3, 99-113.

[10] Ochi, S. (2012) Fabrication of Press-Molded Products Using Bamboo Powder. Journal of Materials Science Research, 1, 156-166.

[11] Ochi, S., Takagi, H. and Niki, R. (2002) Mechanical Properties of Heat-Treated Natural Fibers. In: Brebbia, C.A. and De Wilde, W.P., Eds., High Performance Structures and Composites, 117-125.

[12] Testa, G., Sardella, A., Rossi, E., Bozzi, C. and Seves, A. (1994) The Kinetics of Cellulose Fiber Degradation and Correlation with Some Tensile Properties. Acta Polymer, 45, 47-49. http://dx.doi.org/10.1002/actp.1994.010450109

[13] Osswald, T.A. and Menges, G. (2003) Materials Science of Polymers for Engineers. 2nd Edition, Hanser Publications, Munich. 
Scientific Research Publishing (SCIRP) is one of the largest Open Access journal publishers. It is currently publishing more than 200 open access, online, peer-reviewed journals covering a wide range of academic disciplines. SCIRP serves the worldwide academic communities and contributes to the progress and application of science with its publication.

Other selected journals from SCIRP are listed as below. Submit your manuscript to us via either submit@scirp.org or Online Submission Portal.
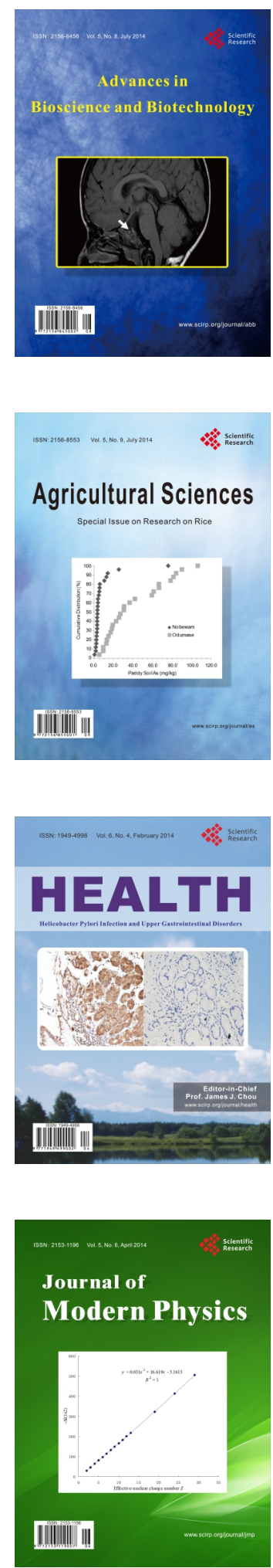
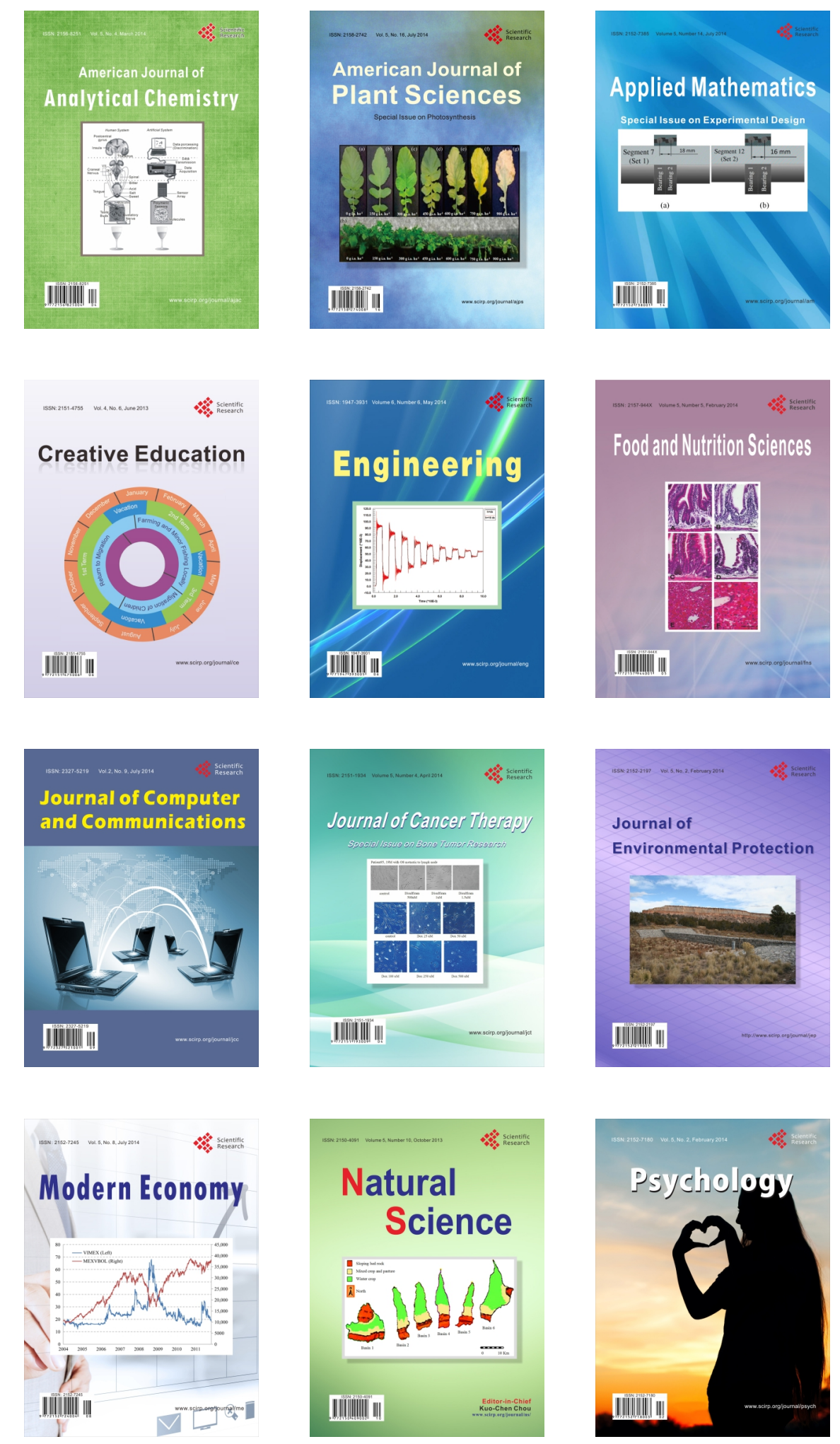